\title{
ME-REVIEW KONTROVERSI UJIAN NASIONAL 2021
}

REVIEW THE CONTROVERT OF THE NATIONAL EXAM 2021

\author{
BAHAUDIN \\ SMP Satap Tenjo Ayu 2 \\ Alamat: Jl. Tanggul Sungai Ciujung Desa Tengkurak, Kec. Tirtayasa \\ Kab. Serang - Banten
}

\begin{abstract}
Abstrak
Penelitian ini menggunakan metode kualitatif, yaitu metode yang memunyai karakteristik alami (natural setting) sebagai sumber data langsung, deskriptif, proses lebih dipentingkan dari pada hasil, analisis dalam penelitian kualitatif cenderung dilakukan secara analisis induktif serta makna merupakan hal yang esensial. Pada metode penelitian, penulis melakukan beberapa langkah, diantaranya: teknik analisis data, teknik pengumpulan data, sampel sumber data, Instrumen Penelitian, dan tempat penelitian. Hasil penelitaian pada journal ini membahas: tinjauan ujian nasional (UN) dalam sistem pendidikan nasional, strategi perancangan ujian nasional (UN), dan perlu-tidaknya ujian nasional (UN) sebgai alat evaluasi.
\end{abstract}

KataKunci: Review, Kontroversi, Strategi, Evaluasi, Hasil

\begin{abstract}
This study uses qualitative methods, namely methods that have natural characteristics (natural setting) as a source of direct data, descriptive, process is more important than the results, analysis in qualitative research tends to be done inductively and meaning is essential. In the research method, the authors do several steps, including: data analysis techniques, data collection techniques, sample data sources, research instruments, and research sites. The research results in this journal discuss: a review of the national exam (UN) in the national education system, the strategy of designing a national exam (UN), and the need for a national exam (UN) as an evaluation tool.
\end{abstract}

Keywords: Review, Controversy, Strategy, Evaluation, Result.

\section{PENDAHULUAN}

Review adalah suatu tinjauan, ringkasan, atau tinjauan ulang. Ada yang disebut sebagai review text atau text review yang memiliki pengertian sebagai teks yang berfungsi untuk memberikan penilaian, kritik atau tanggapan terhadap suatu kegiatan, karya seni atau produk bagi pembaca atau pendengar. Ada juga yang mengartikan sebuah ringkasan, tinjauan dari beberapa sumber baik dari film, buku, berita dan lainnya. Tujuannya review adalah untuk 
memberi informasi ke pembaca tentang suatu hal dan mengajaknya atau membuat pembeca semakin penasaran. Kegiatan me-review ini sangat penting untuk peningkatan hasil yang hendak dicapai.

Sementara ujian nasional biasa disingkat UN adalah sistem evaluasi standar pendidikan dasar dan menengah secara nasional dan persamaan mutu tingkat pendidikan antar daerah yang dilakukan oleh Pusat Penilaian Pendidikan, Depdiknas di Indonesia berdasarkan Undang-undang Republik Indonesia nomor 20 tahun 2003 yang menyatakan bahwa dalam rangka pengendalian mutu pendidikan secara nasional dilakukan evaluasi sebagai bentuk akuntabilitas penyelenggara pendidikan kepada pihak-pihak yang berkepentingan. Lebih lanjut dinyatakan bahwa evaluasi dilakukan oleh lembaga yang mandiri secara berkala, menyeluruh, transparan, dan sistematik untuk menilai pencapaian standar nasional pendidikan dan proses pemantauan evaluasi tersebut harus dilakukan secara berkesinambungan.

Proses peninjauan evaluasi tersebut dilakukan secara terus menerus dan berkesinambungan pada akhirnya akan dapat membenahi mutu pendidikan. Pembenahan mutu pendidikan dimulai dengan penentuan standar. Penentuan standar yang meningkat diharapkan akan mendorong peningkatan mutu pendidikan, yang dimaksud dengan penentuan standar pendidikan adalah penentuan nilai batas (cut off hiscore). Seseorang dikatakan sudah lulus/kompeten bila telah melewati nilai batas tersebut berupa nilai batas antara peserta didik yang sudah menguasai kompetensi tertentu dengan peserta didik yang belum menguasai kompetensi tertentu. Bila itu terjadi pada ujian nasional atau sekolah maka nilai batas berfungsi untuk memisahkan antara peserta didik yang lulus dan tidak lulus disebut batas kelulusan, kegiatan penentuan batas kelulusan disebut standard setting.

Di lain sisi banyak juga yang menganggap tidak perlu lagi adanya evaluasi siswa, hal ini karena adanya pertimbangan setelah melihat fenomena yang terjadi. Evaluasi sebagai sarana hiburan bagi dinas pendidikan setempat, sekolah, kepala sekolah, dewan guru dan para siswa. Bahkan ada beberapa pihak evaluasi siswa di akhir masa pendidikan siswa, sekolah menjadikannya sebagai ajang bisnis. Banyak sekolah yang 
menjadikan UN sebagai alat untuk menarik siswa mengikuti program sekolah. Siswa diwajibkan mengikuti Study Tour sebagai syarat mengikuti Ujian Nasional. Padahal jika sekolah tersebut kreatif ada dana BOS (Bantuan Operasional Sekolah) yang bisa dialokasikan untuk kegiatan tersebut. Misalnya, pertimbangan jarak dan waktu dengan biaya anggaran yang disubsidi dari bantuan Pemerintah tersebut. Sekolah hanya memanfaatkan pada kegiatan tersebut tanpa mengedepankan harapan dari hasil UN. Dari beberapa gambaran di atas menarik penulis untuk membahasnya kedalam penelitian dengan judul "Me-Review Perlu tidaknya Ujian Nasional (UN)".

\section{KAJIAN TEORETIK}

Sebagaiman telah dijelaskan pada bagian sebelumnya bahwa kata "Re-view" berasal dari frase "re" yang berarti kembali dan "view" yang berarti meninjau. Dengan demikian mereview adalah meninjau kembali suatu kasus atau permasalahan. Menurut istilah review adalah sebuah ringkasan, tinjauan dari beberapa sumber baik flm, buku, berita dan lainnya. Review sering digunakan dalam kegiatan pemasaran dengan tujuan untuk memberi informasi kepada pembaca atau pemirsa tentang suatu hal sehingga menjadi penasaran.

Sementara kontroversi menurut Kamus Besar Bahasa Indonesia adalah menimbulkan perdebatan. Menurut istilah kontroversi adalah suatu pertentangan atau suatu perdebatan terhadap sebuah masalah yang bertentangan yang memiliki dua sisi yang berlainan yang bisa memicu konflik. Kontroversi adalah hal yang biasa terjadi dan sebaiknya menyikapinya dengan arif dan saling menghormati. Semua orang mempunyai pemikiran dan pendapat yang berbeda. Pada penelitian ini, penulis bukan membuka adanya perdebatan perlu tidaknya pelaksanaan UN sebagai alat evaluasi, namun melalui tulisan ini mengajak pembaca untuk lebih bijak menerima kebijakan. Dari pada sibuk dengan kontroversi alangkah lebih baik kita memikirkan hal-hal penting yang mesti dilakukan.

Ujian Nasional yang dikenal dengan UN adalah sistem evaluasi standar pendidikan dasar dan menengah secara nasional dan persamaan mutu tingkat pendidikan antar daerah yang dilakukan oleh Pusat Penilaian Pendidikan. Depdiknas di Indonesia berdasarkan 
Undang-Undang Republik Indonesia nomor 20 tahun 2003 menyatakan bahwa dalam rangka pengendalian mutu pendidikan secara nasional dilakukan evaluasi sebagai bentuk akuntabilitas penyelenggara pendidikan kepada pihak-pihak yang berkepentingan.

Lebih lanjut dalam undangundang menyatakan bahwa evaluasi dilakukan oleh lembaga yang mandiri secara berkala, menyeluruh, transparan, dan sistematik untuk menilai pencapaian standar nasional pendidikan dan proses pemantauan evaluasi tersebut harus dilakukan secara berkesinambungan. Proses pemantauan evaluasi tersebut dilakukan secara terus menerus dan berkesinambungan pada akhirnya akan dapat membenahi mutu pendidikan. Pembenahan mutu pendidikan dimulai dengan penentuan standar.

Sejarah perkembangan ujian nasional (UN) secara berkala (periodik), yaitu: Pertama Ujian Negara 1965 - 1971 yang bertujuan untuk menentukan kelulusan, sehingga siswa dapat melanjutkan ke sekolah negeri atau perguruan tinggi negeri apabila telah lulus ujian negara. Sedangkan bagi yang tidak lulus ujian negara tetap memperoleh ijazah dan dapat melanjutkan ke sekolah atau perguruan tinggi swasta. Kedua, Pada 1972-1979 adalah Ujian Sekolah. Ujian negara sempat dihapuskan. Penghapusan ujian kesetaraan nasional lantas dikritik pakar pendidikan. Pada masa itu dunia pendidikan mengalami keterpurukan. Anak yang tidak lulus ujian sekolah dianggap biasa. Sementara sekolah-sekolah saat itu seenaknya dalam menentukan kriteria kelulusan. Akibatnya, mutu pendidikan kala itu hanya 40 persen yang sesuai standar. Ketiga, Evaluasi Belajar Tahap Nasional atau disingkat EBTANAS dan EBTA, yaitu di tahun 1980 - 2002. Tujuan dari evaluasi ini sebagaimana liputan6.com menyatakan adalah untuk memperoleh Surat Tanda Tamat Belajar (STTB). Keempat, Ujian Akhir Nasional (UAN) tahun 2003 - 2004.

\section{METODE PENELITIAN}

Pada penelitian ini penulis menggunakan pendekatan kualitatif, yang memunyai karakteristik alami (natural setting) sebagai sumber data langsung, deskriptif, proses lebih dipentingkan dari pada hasil, analisis dalam penelitian kualitatif cenderung dilakukan secara analisis induktif serta makna merupakan hal yang 
esensial. Terdapat 6 (enam) macam metodologi penelitian yang menggunakan pendekatan kualitatif, yakni: etnografis, studi kasus, grounded theory, interaktif, partisipatories, serta penelitian tindakan kelas.

Penelitian ini berlokasi di tempat penulis bekerja, yaitu SMPN Satap Tenjo Ayu 2, Jl. Tanggul Sungai Ciujung Desa Tengkurak, Kec. Tirtayasa dengan alasan karena berdasarkan pada beberapa pertimbangan: 1) Lebih mudah akses, 2) Mengenal obyek penelitian, dan 3) obyek penelitian menarik untuk dikaji.

\section{HASIL PENELITIAN DAN PEMBAHASAN}

Pada bagian ini, penulis akan membahas tiga pokok bahasan yang menjadi inti permasalahan, di antaranya: Tinjauan ujian nasional (UN) dalam Sistem Pendidikan Nasional, Strategi Perancangan Ujian Nasional, dan Perlu-tidaknya Ujian Nasional (UN) sebagai Alat Evaluasi.

Kebijakan pemerintah mengenai ujian nasional (UN), memang selalu mendapat respon dari masyarakat baik pro dan kontra. Walaupun secara mendasar, ujian nasional sebenarnya ditujukan untuk meningkatkan kualitas pendidikan nasional. Umumnya, kelompok yang kontra terhadap ujian nasional, mendasarkan ketidak setujuannya pada fakta empiris yang terjadi selama ujian nasional diberlakukan. Sehingga masyarakat yang kontra terhadap kebijakan ujian nasional mengharapkan adanya peningkatan kualitas guru dan kualitas pendidikan terlebih dahulu sebelum diselenggarakannya ujian nasional. Selain itu, ada pula yang menyarankan agar ujian akhir cukup dilakukan sekolah, karena sekolah yang tahu tentang perkembangan siswa dan sekolah yang bertanggungjawab atas pencapaian belajar siswa.

Akhirnya, berdasarkan berbagai pandangan, munculah beberapa saran untuk perbaikan UN diantaranya: (1) Ujian nasional jalan terus dengan beberapa perbaikan untuk mendorong guru mengajar, mendorong siswa belajar dan untuk kesatuan bangsa, (2) Ujian nasional dilaksanakan apabila semua standar pendidikan sudah dipenuhi, (3) Hasil ujian nasional hanya digunakan untuk pemetaan kualitas pendidikan saja, bukan untuk menentukan kelulusan dari satuan pendidikan, (4) Kelulusan peserta didik dari satuan pendidikan ditentukan oleh sekolah atau guru saja. 
Berdasarkan saran yang dikemukakan oleh berbagai pihak, maka pemerintah yang berwenang dalam penyelenggaraan pendidikan nasional senantiasa melakukan perbaikan dalam penyelenggaraan UN. Sebenarnya, produk kebijakan berupa UN bukanlah hal baru dalam praksis pendidikan nasional. UN telah lama ada dalam penyelenggaraan pendidikan nasional, namun UN dikenal dengan berbagai istilah dalam periode penyelenggaraannya. Wacana akan adanya upaya perbaikan ujian nasional pada tahun pelajaran mendatang, memerlukan adanya kajian untuk dapat memahami wacana yang dikemukakan.

Mendikbud Nadiem Makarim berencana mengganti format syarat kelulusan siswa dari ujian nasional ke asesmen kompetensi dan survei karakter. Rencananya penggantian tersebut akan efektif mulai 2021. Soal-soal yang diberikan nantinya tidak akan membuat siswa menghafal, namun melahirkan daya analisis berdasarkan suatu informasi. Makanya topiknya hanya dua, yakni kemampuan literasi dan kemampuan numerasi.

Sebelum membahas perlutidaknya ujian nasional diberlakukan, terlebih dahulu penulis kemukakan strategi-strategi yang dilakukan pihak sekolah (dalam hal ini guru/pendidik) untuk meningkatkan prestasi siswa, yaitu: (1) Memasyarakatkan program sekolah, (2) Merubah strategi pembelajaran, dan (3) Menambah jam belajar sekolah merumuskan program sukses ujian nasional bertolak pada hasil kemampuan siswa. Selain itu juga didasarkan pada potensi lain yang dimiliki oleh pihak sekolah. Strategi dan langkah sukses ujian nasional disosialisasikan pada orang tua atau wali murid. Tujuannya agar semua orang tua siswa mengetahui dan ikut berpartisipasi mendukung program sukses UN yang dicanangkan sekolah.

1. Merubah strategi pembelajaran.

Mengubah strategi pembelajaran di kelas pada tingkat terakhir, dari berorientasi pada materi pelajaran ke orientasi ujian nasional yang akan dilaksanakan. Otomatis dalam setiap pembelajaran ini guru memiliki berbagai perangkat selain perangkat mengajar. Yang dimaksud disini adalah kisi-kisi untuk ujian nasional, seperti mengerjakan soal-soal UN. Dengan demikian siswa lebih banyak diberi soal-soal. Baik dikerjakan di sekolah maupun sebagai pekerjaan rumah. 
2. Menambah jam belajar.

Program belajar tambahan dinilai cukup efektif selama ini dalam meraih hasil yang memuaskan. Bentuk program ini dilakukan oleh sekolah pada sore hari khususnya mata pelajaran yang masuk dalam UN. Biasanya pihak sekolah bekerja sama dengan lembaga bimbingan belajar, namun ada yang murni dilaksanakan oleh guru di sekolah.

3. Penguasaan materi dan peningkatan kualitas pembelajaran.

Anak sering dituntut untuk selalu belajar dan menyerap semua ilmu dan pengetahun yang diberikan oleh gurunya. Guru mengajar di kelas dan memberikan pembelajaran sesuai dengan ilmu yang dimilikinya. Kadang-kadang kemampuan guru dalam menyampaikan materi kurang disukai anak dan bahkan tidak mampu menyampaikannya secara baik kepada anak didik. Hal ini akan berpengaruh terhadap peningkatan kompetensi anak dalam mencapai prestasi terbaiknya. Untuk itu agar anak bisa mencapai kompetensi yang maksimal guru juga harus bersedia meningkatkan kualitas pembelajarannya baik dalam penguasaan materi maupun cara penyampaiannya kepada anak didik. Pemberian soal-soal secara terus menerus tentu bukanlah cara yang baik dan efektif yang bisa diterima anak. Anak didik membutuhkan pemahaman pengetahuan dengan bimbingan dari gurunya. Bila guru bersedia melakukan pembimbingan dengan baik harapnnya anak didik bisa mengoptimalkan prestasinya.

4. Pemenuhan buku ajar dan pengayaan.

Untuk mendukung tercapainya prestasi yang optimal anak didik perlu dipenuhi dengan ketersediaan bahan ajar dan bukubuku pengayaan. Buku kumpulan soal bukanlah solusi yang baik bagi siswa untuk bisa belajar meningkatkan kompetensinya. Buku-buku pengayaan juga diperlukan agar anak bertambah wawasan dan memiliki kemampuan pemahaman yang bisa diandalkan.

5. Dukungan orang tua.

Orang tua memiliki peran yang sangat utama. Di sekolah anak didik dibimbing dan dilatih oleh gurunya. Guru memberi mereka materi pelajaran dan 
membimbingnya untuk memahami konsep-konsep yang dibutuhkan. Orang tua di rumah melengkapinya dengan memberikan motivasi agar anak tidak cepat melupakan materi yang diperolehnya selama di sekolah.

Faktor-faktor pendukung itu bisa dijadikan sebagai acuan strategi penyusunan program oleh sekolah untuk mencapai target yang diinginkan. Nilai ujian anak didik secara rata-rata bisa meningkat dan sekolah juga mendapatkan "hasil" dari perjuangan memberikan pembelajaran yang terbaik pada anak didiknya.

Pada bagian ini akan dibahas dampak positif dan negatif pelaksanaan ujian nasional (UN) terhadap stakeholder pendidikan. Ada beberapa pendapat berkaitan dengan sisi positif dan negatif terhadap pelaksanaan jenis evaluasi (baca, UN) tersebut.

Pro dan kontra terhadap kebijakan pemerintah yang memutuskan untuk menghapus Ujian Nasional terjadi akhir-akhir ini, terutama dalam dunia pendidikan. Ujian Nasional bagi beberapa siswa, orangtua, guru, dan sekolah adalah sesuatu yang menyeramkan. Akan tetapi, tak sedikit juga yang memandang bahwa penghapusan UN justru akan merugikan dunia pendidikan Indonesia. Dampak positif dan negatif ditiadakannya ujian nasional dari berbagai stakeholder, yaitu di antaranya bagi:

1. Pemerintah, keuntungannya adalah mengurangi beban anggaran Pemerintah untuk menyelenggarakan UN. Kerugiannya adalah akan kesulitan untuk mengukur evaluasi belajar siswa dan tingkat kemajuan pendidikan nasional. Akan semakin sulit untuk melakukan pemerataan terhadap kualitas pendidikan di tiap daerah, karena tingkat kesulitan soal-soal ujian dan kriteria kelulusan yang dibuat oleh pemerintah daerah akan berbeda-beda.

2. Sekolah dan Guru, keuntungannya adalah merasa lebih dihargai oleh pemerintah karena pemerintah mempercayakan penilaian kelulusan siswa di tangan mereka. Kesuksesan sekolah dan para guru tidak lagi dinilai hanya dari berhasil atau tidaknya mereka meluluskan siswanya dalam Ujian Nasional. Kerugiannya adalah Minat dan ketekunan siswa untuk belajar kemungkinan akan turun karena merasa tidak ada syarat 
kelulusan yang seketat Ujian Nasional dari Pemerintah.

3. Siswa, keuntungannya adalah berkurangnya beban psikologis, dan lebih fokus kemata pelajaran yang diminati. Kerugiannya adalah siswa kehilangan satu motivasi dan alasan untuk belajar lebih serius.

4. Orang tua, keuntungannya adalah anak yang memiliki bakat dan prestasi sangat baik di suatu bidang namun memiliki kekurangan dalam mata pelajaran yang diujikan dalam UN. Dapat lebih mudah membimbing anaknya untuk lebih fokus di bidang yang menjadi kelebihan si anak. Kerugiannya adalah orang tua akan kesulitan dalam menilai kualitas pendidikan sebuah sekolah.

\section{SIMPULAN}

Simpulan yang dapat penulis berikan pada penelitian kualitatif ini adalah sebagai berikut:

1) Produk kegiatan berupa UN sebenarnya bukanlah hal baru dalam sistem pendidikan Nasional. UN telah lama ada dalam penyelenggaraan

pendidikan Nasional, namun dikenal dengan berbagai istilah/nama dalam tiap periodenya. Dalam wewenangnya melakukan perbaikan penyelenggaraan pendidikan, Pemerintah acapkali melakukan tinjauan ujian nasional sebagai upaya meningkatkan mutu pendidikan

2) Strategi perencanaan ujian nasional (UN) meliputi: memasyarakatkan program sekolah, merubah strategi pembelajaran, dan menambah jam belajar.

3) Pro dan kontra terhadap kebijakan pemerintah yang memutuskan untuk menghapus Ujian Nasional terjadi akhir-akhir ini, terutama dalam dunia pendidikan. Ujian Nasional bagi beberapa siswa, orang tua, guru, dan sekolah adalah sesuatu yang menyeramkan. Dampak positif dan negatif ditiadakannya ujian nasional dari berbagai stakeholder sebagaimana telah dijelaskan pada akhir penelitian menjadi acuan dalam menentukan format yang tepat untuk melihat hasil pendidikan anak Bangsa.

\section{DAFTAR PUSTAKA}

http://pendidikanekonomipemasaran.b logspot.com/2014/11/kelebihan- 
dan-kelemahan-ujian-

Diakses

nasional.html.

17/01/2020 jam 15:24.

https://mediaindonesia.com/read/detai

1/277115-ini-sejarah-ujian-

nasional-di-indonesia. Diakses

17/1/2020 jam 23:11.

https://www.liputan6.com/news/read/4

133109/transformasi-nama-un-

mulai-dari-ujian-penghabisan-

hingga-ebtanas.

Diakses

18/1/2020 jam 0:47

H. McMillan, James. Assessment

Essentials for Standards-Based

Education, Corwin Press, 2008.

Moleong, Lexy. Metodologi Penelitian

Kualitatif . Bandung: PT.

Remaja Rosda Karya, 2002.

Pusparisa, Yosepha. Ujian Nasional

Segera Berganti Wujud.

https://katadata.co.id/infografik/2

019/12/25/ujian-nasional-

segera-berganti-wujud. Diakses

18/1/2020 jam 2:27.

Sugiyono. Metodologi Penelitian

kuantitatif kualitatif dan $R \& D$.

Bandung: Alfabeta, 2006.

Undang-Undang Republik Indonesia nomor 20 tahun2003

Wahyuningtyas, Sri, dan Wijaya Heru

Santosa. Sastra: Teori dan

Implementasi. Surakarta: Yuma

Pustaka, 2011.

(https://news.detik.com/opini/d- 2232694/ujian-nasional-dan-

faktanya. Diakses 17/01/2020 jam 14:53.)

Yusuf Tayib Napis, Farida. Evaluasi Program. Jakarta: Rineka Cipta, 2000.

Zagranski, Richard., William T. Whigham, Patrice L. Dardenne, Understanding Standards-based Education: A Practical Guide for Teachers and Administrators, Corwin Press, 2007. 